J. Clin. Chem. Clin. Biochem.

Vol. 26, 1988, pp. 655-658

(C) 1988 Walter de Gruyter \& Co.

Berlin - New York

\title{
Dextran Determination in Human Serum with the Aid of an Enzymatic Glucose Method
}

\author{
By L. F. Gabel, H. E. M. Kerkkamp
}

Institute of Anaesthesiology, Catholic University of Nijmegen, The Netherlands and

\section{J. N. Nederstigt}

Laboratory of the Institute for Obstetrics and Gynaecology, Catholic University of Nijmegen, The Netherlands

(Received January 26/June 23, 1988)

Summary: A method is presented for the determination of dextran concentrations. Following acid hydrolysis and partial neutralization, the resulting glucose is determined with the aid of glucose oxidase. Specificity is better than that of previously applied methods. Mean recovery is $100.2 \pm 1.6 \%$ (SD) for concentrations from $180 \mathrm{mg} \cdot 1^{-1}$ to $6000 \mathrm{mg} \cdot 1^{-1}$. Coefficients of variation are $2.2 \%$ for $240 \mathrm{mg} \cdot 1^{-1}, 1.2 \%$ for $600 \mathrm{mg} \cdot 1^{-1}$ and $1.8 \%$ for $1200 \mathrm{mg} \cdot 1^{-1}$. When used for volume measurements, the accuracy is $99.3 \pm 2.1 \%$ (SD) for volumes of 2.5 to 3 liters.

\section{Introduction}

Dextrans are used widely as plasma substitutes and antithrombotic agents. The fact that they are well retained intravascularly also makes them suitable for vascular permeability research and for plasma volume measurement with a dilution technique. Dextran concentrations have been determined in several different ways: estimation of reducing power according to $\mathrm{Ha}$ gedorn-Jensen after acid hydrolysis (1), complex formation with copper (2), serological (3), polarimetric (4), carbohydrate determination with anthrone and sulphuric acid $(5,6)$ and turbidimetrically $(7)$. These methods are lacking either in sensitivity or in specificity, which has complicated their ùse and necessitated many modifications $(8-13)$.

In the method described here, dextran is hydrolysed to glucose by heating with hydrochloric acid accord-

1) Enzymes:

1. Glucose oxidase $(\dot{\beta}-D$-glucose : oxygen oxidoreductase, EC 1.1.3.4)

2. Hexokinase (ATP : D-hexose 6-phosphotransferase, EC 2.7.1.1)

3. Peroxidase (donor : hydrogen-peroxide oxidoreductase, EC 1.11.1.7) ing to Gohr, Bolte \& Langenberg (1); the glucose is finally determined not chemically through its reducing power, but enzymatically with the aid of a commercial kit (GOD-PAP, see below under procedure) containing glucose oxidase and peroxidase, ${ }^{1}$ ) thereby enhancing sensitivity and specificity. Glucose oxidase was previously used in dextran determinations only to remove glucose from samples before hydrolysis (11). The dextran preparation used in our experiments was a $6 \%$ dextran 70000 solution in $9 \mathrm{~g} / \mathrm{l} \mathrm{NaCl}$, containing dextran with a mean relative molecular mass of 70000 (NPBI, batch Nr. 8610131101).

\section{Procedure}

\section{Required reagents}

Hydrochloric acid $6 \mathrm{~mol} / \mathrm{l}$ (add $300 \mathrm{ml} \mathrm{HCl} \mathrm{37 \%} \mathrm{-} \mathrm{Merck}$ cat. No. 317.1000 - to water, and adjust volume to 500 $\mathrm{ml)}$

Sodium hydroxide $262.5 \mathrm{~g} \cdot 1^{-1}$ (dissolve $52.2 \mathrm{~g} \mathrm{NaOH}-$ Merck cat. No. 6498.1000 - in water, and adjust volume to $200 \mathrm{ml}$ )

Glucose oxidase-phenol-aminophenazone reagent (GODPAP - Boehringer Mannheim cat. No. 166 391) 
To $1.0 \mathrm{ml}$ of serum were added $0.1 \mathrm{ml}$ of demineralised water (to fit the calibration line, see below) and $0.5 \mathrm{ml}$ of $6 \mathrm{~mol} / \mathrm{l}$ hydrochloric acid in $15 \mathrm{ml}$ glass test tubes. Acid was added while mixing thoroughly on a vortex mixer. Tubes were sealed with glass marbles and placed in a boiling waterbath for $\mathbf{7 5}$ minutes to hydrolyse the dextran. The tubes were then cooled in cold water for 2 minutes and subsequently centrifuged for 25 minutes at $2100 \mathrm{~g}$ (or for 35 minutes at $1300 \mathrm{~g}$ ). Supernatant $(0.5 \mathrm{ml})$ was pipetted into $3 \mathrm{ml}$ test tubes and partially neutralized by the addition of $0.150 \mathrm{ml}$ of the sodium hydroxide solution with thorough mixing.

The remaining part of the determination was done with the aid of a compact clinical analyzer and the KONE sample processor.

Volumes taken from samples and reagents were adjusted with the sampling unit. For dextran determinations $0.020 \mathrm{ml}$ of sample was added to $0.500 \mathrm{ml}$ of the GOD-PAP reagent. For routine glucose determinations, $0.010 \mathrm{ml}$ of sample was added to the reagent. The incubation time was 30 minutes at room temperature. Absorbance was subsequently read at $510 \mathrm{~nm}$ with the analysing unit, which also calculated glucose concentrations (in the case of glucose determinations) or glucose equivalents (in the case of dextran determinations) from the absorbances of simultaneously measured duplicate glucose-free blanks and glucose standard solutions. The glucose standard solutions were prepared in our laboratory, using glucose dissolved in a $6 \mathrm{~g} / \mathrm{l}$ benzoic acid solution in water, containing 9.0 $\mathrm{mmol} \cdot 1^{-1}$ for routine glucose determinations or $4.5 \mathrm{mmol} \cdot 1^{-1}$ for dextran determinations. The setting of the reference concentration for the analysing units was left unchanged at 9.0 $\mathrm{mmol} \cdot 1^{-1}$ for dextran determinations in order to expand the scale; thus, glucose equivalents $=\frac{\mathrm{E}_{\text {sample }}}{\mathrm{E}_{4.5}} \times 9$.

\section{Experimental}

\section{Determination of optimal boiling time}

Triplicate test tubes containing $1.0 \mathrm{ml}$ of mixed serum, $0.1 \mathrm{ml}$ of a $12000 \mathrm{mg} \cdot 1^{-1}$ dextran solution prepared from the $6 \%$ solution and $0.5 \mathrm{ml} 6 \mathrm{~mol} / 1 \mathrm{HCl}$ were placed in a boiling waterbath and removed at 10 minute intervals. One set of tubes was not boiled at all and served as a blank. For this part of the experiments samples were neither centrifuged nor neutralised with $\mathrm{NaOH}$. Glucose concentrations were determined as described under Procedure. The glucose concentration reached a constant level after $60 \mathrm{~min}$ utes and remained constant till 90 minutes, after which evaporation effects became noticeable. An optimal boiling time of $75 \mathrm{~min}$ was therefore chosen (fig. 1).

\section{Determination of the optimal amount of neu. tralisation}

The addition of more than $0.010 \mathrm{ml}$ of the unneutralized hydrolysate to the enzyme solution, for the purpose of increasing sensitivity, caused a decrease in the recovery of the assay. This negative effect was overcome by neutralizing the hydrolysate. The required amount of $\mathrm{NaOH}$ was determined as follows: duplicate test tubes containing $1.0 \mathrm{ml}$ of mixed serum, $0.1 \mathrm{ml}$ of a $12000 \mathrm{mg} \cdot 1^{-1}$ dextran solution and 0.5 $\mathrm{ml}$ of $6 \mathrm{~mol} / \mathrm{l} \mathrm{HCl}$ were placed in a boiling waterbath for 75 minutes. After centrifuging, $262.5 \mathrm{~g} \cdot 1^{-1} \mathrm{NaOH}$ solution was added to $0.500 \mathrm{ml}$ of the supernatant, in volumes between $0.125 \mathrm{ml}$ and $0.225 \mathrm{ml}$. The $\mathrm{pH}$ of these samples ranged from 0.4 to 13.2 as indicated in figure 2 . Subsequently 0.020 mliof the samples was added to $0.500 \mathrm{ml}$ of GOD-PAP reagent in order to determine glucose equivalents (fig. 2). The optimal volume of $\mathrm{NaOH}$ was found to be $0.150 \mathrm{ml}$. This resulted in a pH of 6.55 instead of the normal 7.00 in the final incubation mixture containing the GODPAP reagent.

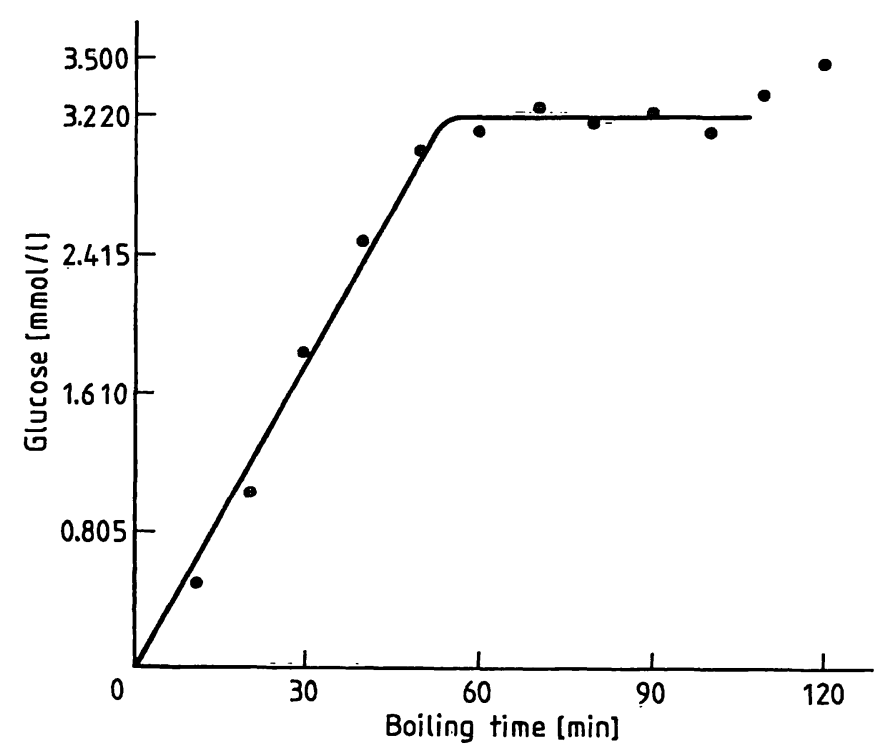

Fig. 1. Optimal boiling time

Glucose concentration measured in samples removed from boiling waterbath at 10 -minute intervals $(n=2)$.

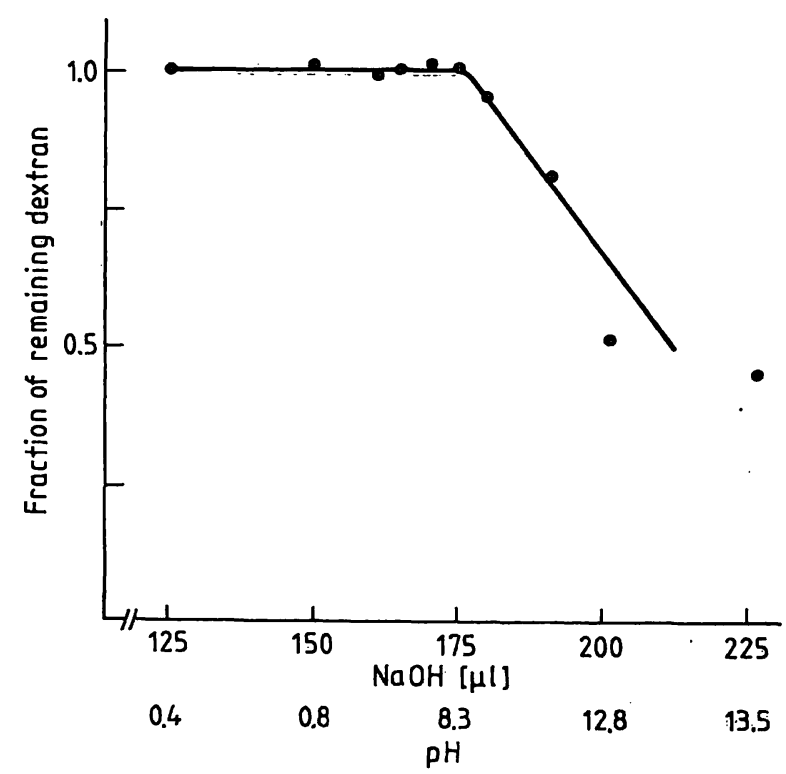

Fig. 2. Optimal volume of added $\mathrm{NaOH}$

Dextran value and $\mathrm{pH}$ measured in samples with 0.150 to $0.225 \mathrm{ml}$ of $262.5 \mathrm{~g} \cdot \mathrm{l}^{-1} \mathrm{NaOH}$ added after hydrolysis $(n=2)$. 


\section{Recovery}

Recovery was determined by measuring glucose concentration in triplicate samples of hydrolysates of mixed serum containing $180,240,420,600,900,1200$, 1500,3000 and $6000 \mathrm{mg}$ dextran per litre and subtracting the glucose concentration of the blanks. Glucose content was calculated from glucose concentration and total sample volume assuming no fluid had been lost by evaporation. Mean recovery was 100.2 $\pm 1.6 \%$ (SD). In mixed serum samples containing 60 , 90 and $120 \mathrm{mg} \cdot 1^{-1}$ recovery was $73 \pm 2.8 \%$ (SD) (tab. 1).

\section{Calibration line}

Calibration lines were drawn for mixed serum as well as for water samples. To $1.0 \mathrm{ml}$ of serum or water was added $0.1 \mathrm{ml}$ of dextran standard solution containing $600,900,1200,1500,1800,2100,2400,3000$, $3750,4500,5250,6000,9000,12000$ or 15000 $\mathrm{mg} \cdot 1^{-1}$. Standard solutions were prepared by diluting $2,3,4,5,6,7,8,9,10,12.5,15,17.5,20,30,40$, and $50 \mathrm{ml}$ of the $6 \%$ dextran solution with water to 200 $\mathrm{ml}$. Water $(0.1 \mathrm{ml})$ was added to the blank samples. Triplicate samples were treated as described under Procedure. The calibration lines were drawn by plotting glucose equivalents against dextran concentration after subtraction of the blanks. The slope of ( $\left.\frac{\text { glucose equivalents }}{\text { dextran concentration }}\right)$ was 0.00527 under the described conditions for both water and mixed serum samples (fig. 3).

\section{Duplication}

Duplication was determined in mixed serum samples containing $240 \mathrm{mg} \cdot 1^{-1}(\mathrm{n}=18), 600 \mathrm{mg} \cdot 1^{-1}$ $(\mathrm{n}=18)$ and $1200 \mathrm{mg} \cdot \mathrm{1}^{-1}(\mathrm{n}=18)$ of dextran. Sam-

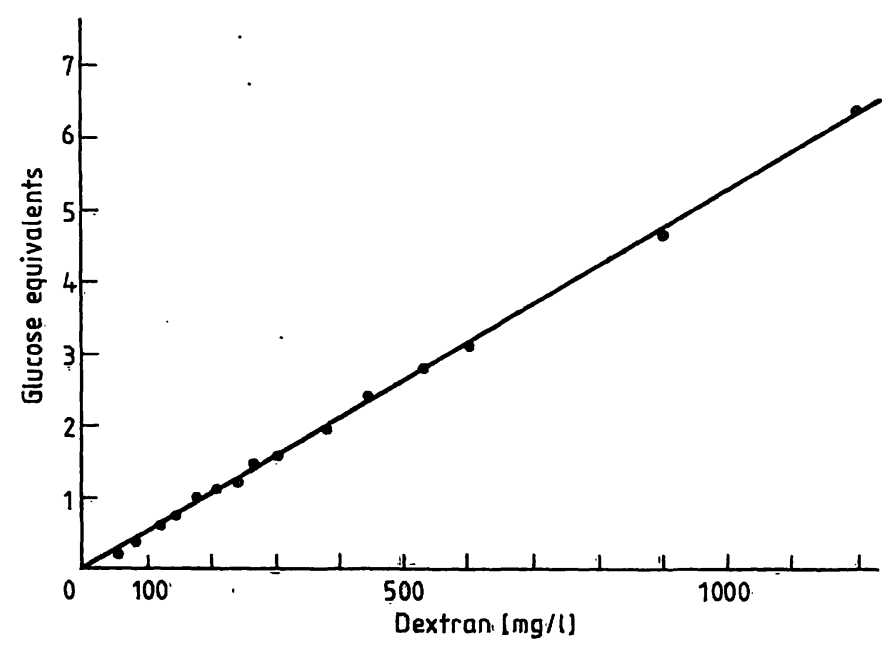

Fig. 3. Calibration line

Glucose equivalents determined from standard dextran solutions in water. The slope is 0.00527 . ples were treated as described under Procedure. The coefficients of variation were $2.2 \%$ for $240 \mathrm{mg} \cdot 1^{-1}$, $1.2 \%$ for $600 \mathrm{mg} \cdot 1^{-1}$ and $1.8 \%$ for $1200 \mathrm{mg} \cdot \mathrm{l}^{-1}$.

\section{Reproducibility}

On 5 different occasions $0.1 \mathrm{ml}$ of a $6000 \mathrm{mg} \cdot 1^{-1}$ dextran solution was added to $1.0 \mathrm{ml}$ of water, and the dextran values were determined in duplicate. The coefficient of variation was $2.1 \%$.

\section{Interfering substances}

The following solutions $(0.2 \mathrm{ml})$ were added to mixed serum $(1.0 \mathrm{ml})$ in order to test their influence on the dextran value of blanks: Geloplasm, Haemaccel, sodium citrate $3.1 \%$, heparin $5000 \mathrm{IE} \cdot \mathrm{ml}^{-1}$, protamine $10 \mathrm{~g} \cdot 1^{-1}$, mannitol $20 \%$ and sorbitol $40 \%$. Blanks consisted of $0.2 \mathrm{ml}$ of water and $1.0 \mathrm{ml}$ mixed serum. The only substance causing an interference was sorbitol; at the test concentration of $6.67 \%$, sorbitol produces an analytical response equivalent to 200 $\mathrm{mg} \cdot 1^{-1}$ of dextran (tab. 2).

Tab. 1. Recovery

Percentage difference for mixed serum samples containing several concentrations of dextran and glucose. Mean recovery for concentrations $120-6000 \mathrm{mg} \cdot 1^{-1}$ was $100.2 \pm 1.6 \%$ (SD). Mean recovery for 60,90 and $120 \mathrm{mg} \cdot 1^{-1}$ was $73 \pm 2.8 \%$ (SD).

\begin{tabular}{ccr}
\hline Dextran added $(\mu \mathrm{g})$ & Glucose found $(\mu \mathrm{g})$ & \multicolumn{1}{c}{$\%$} \\
\hline 60 & 45 & 75.0 \\
90 & 68 & 75.6 \\
120 & 83 & 69.2 \\
180 & 185 & 102.8 \\
240 & 239 & 99.4 \\
420 & 423 & 100.7 \\
600 & 582 & 97.0 \\
900 & 910 & 101.1 \\
1200 & 1205 & 100.4 \\
1500 & 1493 & 99.5 \\
3000 & 3046 & 101.5 \\
6000 & 5957 & 99.3 \\
\hline
\end{tabular}

Tab. 2. Interfering substances

Effect on the glucose equivalent of adding $0.200 \mathrm{ml}$ of various solutions to $1.0 \mathrm{ml}$ of mixed serum (blanks: $0.200 \mathrm{ml}$ water added). Glucose equivalents expressed as $\%$ of blank value $(n=2)$.

\begin{tabular}{lc}
\hline Substance & Glucose equivalents \\
\hline Blank & $100 \pm 0.0 \%$ \\
Geloplasma. & $99.3 \pm 0.7 \%$ \\
Haemaccel. & $97.2 \pm 0.5 \%$ \\
Sodium citrate $3.1 \%$ & $98.5 \pm 0.0 \%$ \\
Heparin $5000 \mathrm{IE} \cdot \mathrm{ml}^{-1}$ & $97.5 \pm 0.6 \%$ \\
Protamine $10 \mathrm{mg} \cdot \mathrm{ml}^{-1}$ & $99.1 \pm 0.2 \%$ \\
Mannitol $20 \%$ & $102.0 \pm 0.5 \%$ \\
Sorbitol $40 \%$ & $119.5 \pm 1.3 \%$ \\
\hline
\end{tabular}




\section{Volume determination}

In order to test the accuracy of the method for volume determination, $40 \mathrm{ml}$ of the $6 \%$ dextran solution were added to known volumes of water and of mixtures of Ringer's solution, Haemaccel, sodium bicarbonate and mannitol as used in extracorporeal circulation, and finally to known volumes actually circulating in extracorporeal circulation (tab. 3). Volumes were calculated according to the equation:

$$
\mathrm{V}=\frac{\mathrm{Q}}{\mathrm{C}}
$$

$(\mathrm{V}=$ volume, $\mathrm{Q}=$ dose, $\mathrm{C}=$ concentration); the mean was $99.3 \pm 2.1 \%$ (SD). The great deviation in one of the extracorporeal circulation volumes (No. 7: $-5.1 \%)$ might be due to insufficient mixing.

Tab. 3. Volume measurements

Volumes measured in $\mathrm{ml}$ by adding $40 \mathrm{ml}$ of dextran $6 \%$ and determining dextran concentration. $\mathrm{ECC}=$ extracorporeal circulation system $(n=4)$.

\begin{tabular}{lllll}
\hline No. & Composition & $\begin{array}{l}\text { Total } \\
\text { volume }\end{array}$ & $\begin{array}{l}\text { Measured } \\
\text { volume }\end{array}$ & $\Delta$ \\
\hline 1 & Water & 3035 & 3080 & $+1.5 \%$ \\
2 & Water & 3035 & 3001 & $-1.1 \%$ \\
3 & Simulated ECC & 2790 & 2746 & $-1.6 \%$ \\
4 & Simulated ECC & 2785 & 2800 & $+0.5 \%$ \\
5 & Simulated ECC & 2815 & 2848 & $+1.2 \%$ \\
6 & ECC & 2435 & 2428 & $-0.3 \%$ \\
7 & ECC & 2835 & 2690 & $-5.1 \%$ \\
\hline
\end{tabular}

\section{References}

1. Gohr, H., Bolte, A. \& Langenberg, H. (1953), Z. Ges. Inn. Med. 8, 773-778.

2. Hint, H. C. \& Thorsén, G. (1947) cited in: Hoppe-Seyler/ Thierfelder, Handbuch der physiologisch- und pathologisch-chemischen Analyse, 10th edn. (Lang, K., Lehnartz, E. \& Siebert, G., eds) pp. 828-829, Springer Verlag, Berlin, Göttingen, Heidelberg.

3. Bull, J. P., Rickets, C., Squire, J. R. Maycock, W. d'A., Spooner, S. J. L., Mollison, P. L. \& Paterson, J. C. S. (1949) Lancet $I, 134-143$.

4. Ingelman, B. (1949) Upsala Läkerefören. Förhandl. 54, $107-122$.

5. Wallenius, G. (1953) Acta Soc. Med. Upsal. 59, 69-77.

6. Dreywood, R. (1946) Ind. Eng. Chem. Anal. Ed. 18, 499.

7. Jacobsson, L. (1957) Acta Soc. Med. Upsal. 63, 212-220.

8. Craig, A. B. \& Waterhouse, C. (1957) J. Lab. Clin. Med. $49,165-171$

\section{Discussion}

The method of determination of dextran concentration presented here has the advantage of improved specificity. Heparin does not interfere, as it does in the turbidimetric method described by Jacobsson (7), and there is no significant interference by hexitols such as mannitol and sorbitol in clinically applied concentrations, which are known to interfere in the anthrone method $(5,6)$. The enzymes in the GODPAP reagent remain active in spite of the high acidity involved. Furthermore, this method is much easier to apply, because no special precautions are necessary, such as extremely dust free reagents, precise temperature and time control, or unusual laboratory equipment, and it may in part even be performed automatically. It does not involve radioactivity, unlike the use of tagged albumin or red blood cells, and in contrast with dye methods it may be applied repeatedly in plasma volume measurements. Disadvantages are the amount of time involved, which makes this method unsuitable for emergency volume assessment, and some risk of allergic reactions (14-16). This risk may be reduced by application of a dextran preparation with a mean relative molecular mass of 1000 . However, this has a different disappearance rate, which will strongly affect the measurements. Separation of light and heavy dextran fractions might be a solution to this problem. Accuracy appears to be sufficient for volumes of the magnitude involved in plasma volume measurement. It was shown that other enzymatic glucose methods (hexokinase, oxygen consumption of glucose oxidase) may be used in place of the GOD-PAP reagent.

9. Semple, R. E. (1957) Can. J. Biochem. Physiol. 35, 383390.

10. Semple, R. E., Thomsen, A. E. T. \& Ball, A. J. (1958) Clin. Sci. $17,511-518$.

11. Appel, W., Wirmer, V. \& Sprengard, D. (1968) Z. Klin. Chem. Klin. Biochem. 6, 452-458.

12. Jermyn, M. A. (1975) Anal. Biochem. 68, 332-335.

13. Hellsing, K., Engström, H. \& Richter, W. (1976) Anal. Biochem. 76, 149-156.

14. Hedin, H., Richter, W., Meßmer, K., Renck, H., Ljungström, K.-G. \& Laubenthal, H. (1981) In: Joint WHO/ IABS symposium on the standardization of albumin, plasma substitutes and plasmapheresis, Geneva 1980. Develop. Biol. Standard. 48, pp. 179-189, S. Karger, Basel.

15. Beez, M. \& Dietl, H. (1979) Infusionstherapie 6, 23-26.

16. Paull, J. (1987) Anaesth. Intens. Care 15, 163-167. drs H. E. M. Kerkkamp Katholieke Universiteit Nijmegen Instituut vöor Anesthesiologie Geert Grooteplein Zuid 10 P.O. Box 9101 NL-6500 HB Nijmegen " 